\title{
Could immune activation cause pancreatitis in COVID-19 patients?
}

\author{
Gabriela Gama Freire Alberca^, Naiane Samira Souza Cardoso^, Ricardo Wesley Alberca^ \\ Laboratorio de Dermatologia e Imunodeficiencias (LIM-56), Departamento de Dermatologia, Instituto de Medicina Tropical, Faculdade de \\ Medicina FMUSP, Universidade de Sao Paulo, Sao Paulo, SP, Brazil \\ Correspondence to: Dr. Ricardo Wesley Alberca. Departamento de Dermatologia, Faculdade de Medicina FMUSP, Laboratorio de Dermatologia e \\ Imunodeficiencias (LIM-56), Universidade de Sao Paulo, Av. Dr. Enéas Carvalho de Aguiar, 470, São Paulo 05403-000, Brazil. \\ Email: ricardowesley@usp.br.
}

Received: 18 February 2021; Accepted: 26 March 2021; Published: 25 October 2022.

doi: $10.21037 /$ tgh-21-21

View this article at: http://dx.doi.org/10.21037/tgh-21-21

We read with really great interest the paper published by Gadiparthi et al. entitled "Acute pancreatitis in a patient with COVID-19: a case report" in Translational Gastroenterology and Hepatology (1). The authors presented a case of elderly, with type 2 diabetes mellitus (T2DM), infected with severe acute respiratory syndrome coronavirus-2 (SARS-CoV-2) that developed pancreatic injury (1). We would like to add a few points for consideration.

Although is possible that a direct SARS-CoV-2 infection occurs in the pancreas, due to the expression of the SARS$\mathrm{CoV}-2$ entry's receptor angiotensin-converting enzyme 2 (ACE 2) receptor. We would like to discuss how the immune response to SARS-CoV-2 could contribute to the development of pancreatitis in coronavirus disease 2019 (COVID-19).

Tumor necrosis factor (TNF) is increased in COVID-19 patients and increases further in T2DM severe COVID-19 patients, this cytokine is associated with both the induction of necroptosis and apoptosis in experimental pancreatitis models (2). TNF has a central role in pancreatitis, as treatment with monoclonal TNF antibody (infliximab) can reduce the parenchymal inflammation and tissue necrosis pancreas (3).

In fact a major feature in pancreatitis is the cellular death by either apoptosis or necroptosis, that could be stimulated or influenced by the severe cytokine storm and inflammatory mediators, produced during COVID-19 (4).

Additionally, COVID-19 patients can develop a gastrointestinal dysbiosis (5), which can increase gastrointestinal permeability, causing bacteria translocation and induce immune activation in the pancreas via toll-like receptors and/or NOD-like receptor family pyrin domain containing-3 (NLRP3) inflammasome (6). The NLRP3 inflammasome lead to the secretion of interleukin (IL)-1 $\beta$, IL-18 and the induction of pyroptosis cell death (6). Further increasing the overall inflammation in COVID-19.

Interestingly, pancreatitis may also increase the gut permeability allowing bacterial translocation, providing a sub sequential local and systemic inflammatory stimulus, that may development into multi-organ damage, and endotoxemia (7).

In addition, pathogen-associated molecular patterns (PAMPs) from the gastrointestinal tract or the damageassociated molecular patterns (DAMPs) from the pancreatic cell death may induce the migration of neutrophils and the generation of local neutrophilextracellular traps (NETs) (8). Importantly, the induction of NETs may also activate trypsinogen in pancreatic cells, further contributing to pancreas inflammation, induction, and the release of DAMPs (8). Generating a pro-inflammatory loop in the pancreas. Especially in COVID-19 patients that already have an increase in circulating neutrophils.

The recognition of PAMPs or DAMPs via pattern recognition receptors (PRR) can lead to myeloid differentiation primary response gene 88 (MyD88) signaling or TIR-domain-containing adapter-inducing interferon- $\beta$ (TRIF) signaling resulting in Factor nuclear

^ ORCID: Gabriela Gama Freire Alberca, 0000-0002-3467-5562; Naiane Samira Souza Cardoso, 0000-0002-3305-6567; Ricardo Wesley Alberca, 0000-0002-3602-3306. 
kappa B (NF- $\mathrm{B})$ activation in pancreatic acinar cells, which may progress to pancreatitis and also the development of cancer (4). Therefore, long-term follow-up on COVID-19 patients should be performed to assess the risk for pancreasassociated comorbidities.

$\mathrm{NF}-\kappa \mathrm{B}$ activation can lead to the activation of the signal transducer and activator of transcription (STAT) 3 and STAT1, and the production of more pro-inflammatory mediators such as IL-6, chemokine (C-C motif) ligand 2 (CCL2), and interferons, that lead to the infiltration of monocytes and T helper (Th) cells. COVID-19 patients commonly present lymphopenia and a deficiency in the regulatory immune response (9), which may also aggravate the pancreas lesion and or fibrosis (10).

In summary, SARS-CoV-2 can infect directly pancreas cells, but the immune activation during COVID-19 also represents a risk for the development of pancreatitis. In this light, further investigations on convalescent COVID-19 patients should assess the pancreas and the risk for pancreasassociated comorbidities.

\section{Acknowledgments}

Funding: RWA has a fellowship from the Fundação de Amparo à Pesquisa do Estado de São Paulo (FAPESP). Grant Numbers: 19/02679-7.

\section{Footnote}

Provenance and Peer Review: This article was a standard submission to the journal. The article did not undergo external peer review.

Conflicts of Interest: All authors have completed the ICMJE uniform disclosure form (available at https://tgh.amegroups. com/article/view/10.21037/tgh-21-21/coif). RWA has a fellowship from the Fundação de Amparo à Pesquisa do Estado de São Paulo (FAPESP). The other authors have no conflicts of interest to declare.

Ethical Statement: The authors are accountable for all aspects of the work in ensuring that questions related to the accuracy or integrity of any part of the work are appropriately investigated and resolved.

Open Access Statement: This is an Open Access article distributed in accordance with the Creative Commons Attribution-NonCommercial-NoDerivs 4.0 International
License (CC BY-NC-ND 4.0), which permits the noncommercial replication and distribution of the article with the strict proviso that no changes or edits are made and the original work is properly cited (including links to both the formal publication through the relevant DOI and the license). See: https://creativecommons.org/licenses/by-nc-nd/4.0/.

\section{References}

1. Gadiparthi C, Mohapatra S, Kanna S, et al. Acute pancreatitis in a patient with COVID-19: a case report. Transl Gastroenterol Hepatol 2021. doi: 10.21037/tgh-20-234.

2. Conrad M, Angeli JP, Vandenabeele P, et al. Regulated necrosis: disease relevance and therapeutic opportunities. Nat Rev Drug Discov 2016;15:348-66.

3. Oruc N, Ozutemiz AO, Yukselen V, et al. Infliximab: a new therapeutic agent in acute pancreatitis? Pancreas 2004;28:e1-e8.

4. Watanabe T, Kudo M, Strober W. Immunopathogenesis of pancreatitis. Mucosal Immunol 2017;10:283-98.

5. Zuo T, Zhang F, Lui GCY, et al. Alterations in Gut Microbiota of Patients With COVID-19 During Time of Hospitalization. Gastroenterology 2020;159:944-55.e8.

6. Hoque R, Mehal WZ. Inflammasomes in pancreatic physiology and disease. Am J Physiol Gastrointest Liver Physiol 2015;308:G643-51.

7. Li Q, Wang C, Tang C, et al. Bacteremia in patients with acute pancreatitis as revealed by $16 \mathrm{~S}$ ribosomal RNA genebased techniques*. Crit Care Med 2013;41:1938-50.

8. Merza M, Hartman H, Rahman M, et al. Neutrophil Extracellular Traps Induce Trypsin Activation, Inflammation, and Tissue Damage in Mice With Severe Acute Pancreatitis. Gastroenterology 2015;149:1920-31.e8.

9. Alberca RW, Andrade MMS, Branco ACCC, et al. Frequencies of CD33+CD11b+HLA-DR-CD14-CD66b+ and CD33+CD11b+HLA-DR-CD14+CD66b- Cells in Peripheral Blood as Severity Immune Biomarkers in COVID-19. Front Med (Lausanne) 2020;7:580677.

10. Demols A, Van Laethem JL, Quertinmont E, et al. Endogenous interleukin-10 modulates fibrosis and regeneration in experimental chronic pancreatitis. Am J Physiol Gastrointest Liver Physiol 2002;282:G1105-12.

doi: $10.21037 / \operatorname{tgh}-21-21$

Cite this article as: Alberca GGF, Cardoso NSS, Alberca RW. Could immune activation cause pancreatitis in COVID-19 patients? Transl Gastroenterol Hepatol 2022;7:45. 